\title{
AUTENTISITAS EPITET "YIOY @EOY" DALAM MARKUS 1:1
}

\author{
Stefanus Kristianto
}

\begin{abstract}
Abstrak: teks Markus 1:1 merupakan salah satu teks Perjanjian Baru yang sering diperdebatkan. Terkait ayat ini, para kritikus teks tidak sependapat mengenai autentisitas epitet vioṽ $\theta \varepsilon o \tilde{v}$ ("Anak Allah"). Meskipun penulis pernah berada dalam kubu yang menolak autentisitas epitet ini, dalam tulisan ini, penulis akan mencoba mengevaluasi ulang bukti eksternal dan internal untuk bacaan ini, dengan memperhatikan beberapa perkembangan terakhir dalam ranah Kritik Teks Perjanjian Baru. Berbeda dengan keyakinan penulis sebelumnya, penulis kini melihat bahwa ada alasan yang kuat untuk mempercayai autentisitas epitet ini.
\end{abstract}

Kata Kunci: Markus 1:1, Kritik Teks, Anak Allah, Pregenalogical Coherence, Kanon Kritik Teks

Abstract: Mark 1:1 is one of the most frequently debated text in the New Testament. As to this verse, textual critics disagree with one another on the authenticity of the epithet vioṽ $\theta \varepsilon o \tilde{v}$ ('Son of God'). Although the author used to deny the authenticity of the epithet, in this paper, he will reevaluate the external and the internal evidences by paying attention to the recent developments in the New Testament Textual Criticism. Unlike his previous conviction, the author now sees that there actually are good reasons to accept the authenticity of the epithet.

Keywords: Mark 1:1, Textual Criticism, Son of God, Pregenealogical Coherence, Canon Of Textual Criticism 


\section{PENDAHULUAN}

Di tengah skeptisisme beberapa sarjana (misalnya Epp dan Parker) mengenai mungkinnya merekonstruksi teks asli, para kritikus teks Perjanjian Baru ternyata justru kian menyadari bahwa sebagian besar teks Perjanjian Baru merupakan teks yang stabil. Dalam sebuah talk-show yang diadakan di Dallas Theological Seminary, Ben Witherington sempat mengutip pernyataan Bruce Metzger yang menyatakan bahwa lebih dari sembilan puluh persen teks Perjanjian Baru sudah berhasil direkonstruksi dengan derajat keyakinan yang relatif tinggi. ${ }^{1}$ Senada dengan itu, Martin Heide berpendapat bahwa rata-rata stabilitas teks Perjanjian Baru (dari teks uji yang dipilihnya) mencapai 92,6 persen, dengan stabilitas tiap-tiap naskah berkisar antara 87,1 persen sampai 99,7 persen. $^{2}$ Holmes juga mengakui bahwa meski ada kecairan (fluidity) dalam level mikro-tekstual, tetapi dalam level makro-tekstual, ia menegaskan bahwa teks Perjanjian Baru merupakan teks yang sangat stabil. ${ }^{3}$

Akan tetapi-meski mayoritas teks Perjanjian Baru merupakan teks yang sangat stabil (sehingga sebagian besar teks

${ }^{1}$ Penekanan oleh penulis. Witherington kemudian melanjutkan bahwa sekitar sepuluh persen sisanya (yang masih belum terlalu jelas bacaan aslinya) tidak memiliki signifikansi doktrinal apapun. Video lengkap diskusi ini bisa diakses di https://www.youtube.com/watch?v=TZi1-AJpA-A (diakses 4 Juni 2018). Band. juga Kurt Aland and Barbara Aland, The Text of the New Testament: An Introduction to the Critical Editions and to the Theory and Practice of Modern Textual Criticism, (trans. Errol F. Rhodes; $2^{\text {nd }}$ edition; Grand Rapids: Eerdmans, 1989), 28.

${ }^{2}$ K. Martin Heide, "Assesing the Stability of the Transmitted Text of the New Testament and the Shepherd of Hermas," dalam Robert B. Stewart, ed., The Reliability of the New Testament: Bart. D Ehrman and Daniel B. Wallace in Dialogue, (Minneapolis: Fortress, 2011), 125-59.

${ }^{3}$ Michael W. Holmes, "Text and Transmission in the Second Century", dalam Stewart, The Reliability of the New Testament, 61-79. 
aslinya bisa direkonstruksi)-tidak bisa dipungkiri bahwa beberapa bagian kecil Perjanjian Baru masih menyisakan ruang keraguan mengenai bacaan manakah yang lebih mungkin autentik. Editor UBS biasanya menandai bagian ini dengan rating $C$ atau $D$. Di antara berbagai teks yang yang kerap diperdebatkan tersebut, teks yang akan menjadi fokus perhatian kali ini ialah Markus 1:1.

Terkait teks ini, para sarjana terbagi menjadi dua kelompok perihal autentisitas epitet "Anak Allah" (vioṽ $\theta \varepsilon o \tilde{)}$ ). Sebagian sarjana berpendapat bahwa epitet ini bukanlah gelar yang autentik (misalnya Ehrman, Head, Marcus, Yarbro-Collins, editor SBLGNT), ${ }^{4}$ sementara sebagian lagi mendukung orisinalitas epitet ini (misalnya Bock, Brooks, Edwards, France, Guelich, Hurtado, Lane, Wasserman, Wessel, Witherington). ${ }^{5}$ Penulis sendiri pernah

${ }^{4}$ Peter M. Head, "A Text-Critical Study of Mark 1:1: 'The Beginning of the Gospel of Jesus Christ'," New Testament Studies 37/4 (October 1991): 621-9; Bart D. Ehrman, The Orthodox Corruption of Scripture: The Effect of Early Christological Controversies on the Text of the New Testament (Oxford: OUP, 1993), 72-5; idem, "The Text of Mark in the Hands of the Orthodox", dalam idem, Studies in the Textual Criticism of the New Testament (Leiden: Brill, 2006), 149-54; Adela Yarbro Collins, Mark. Hermeneia (Minneapolis: Fortress, 2007), 130; Joel Marcus, Mark 1-8. AYBC (New Haven/London: YUP, 2008), 141; Michael W. Holmes, ed., The Greek New Testament: SBL Edition (Atlanta/Bellingham, WA: SBL/Logos, 2010), 67.

5 William L. Lane, The Gospel of Mark. NICNT, (Grand Rapids: Eerdmans, 1974), 41; Walter W. Wessel, "Mark" in Frank E. Gaebelein, (ed.), Expositor's Bible Commentary, (Grand Rapids: Zondervan, 1984), 8: 619. Larry W. Hurtado, Mark. NIBC, (Peabody, MA: Hendrickson, 1989), 23; James A. Brooks, Mark. NAC 23, (Nashville, TN: Broadman \& Holman, 2001), 39; Ben Witherington III, The Gospel of Mark: A Socio-Rhetorical Commentary, (Grand Rapids: Eerdmans, 2001), 69; James R. Edwards, The Gospel According to Mark. PNTC, (Grand Rapids/Leicester: Eerdmans/Apollos, 2002), 25; R. T. France, The Gospel of Mark. NIGTC, (Grand Rapids/Carlisle: Eerdmans/Paternoster, 2002), 48; Robert A. Guelich, Mark 1-8:26. WBC 34a, (Dallas: Word, 2002), 6; David L. Turner and Darrell L. Bock, Matthew and Mark. CBC 11, (Carol Stream, Il: Tyndale House, 2005), 404; Tommy Wasserman, "The 'Son of God' was in the Beginning (Mark 1:1)”, in Journal of Theological Studies 62/1 (2011): 20-50. Di tengah debat ini, sebenarnya ada satu kubu lagi, yakni beberapa sarjana yang memilih untuk tidak memilih. Misalnya Morna D. Hooker, The Gospel 
berada dalam posisi yang menolak autentisitas epitet ini. ${ }^{6}$ Meski demikian, dalam tulisan ini penulis akan mencoba mengkaji ulang autentisitas epitet ini dengan memperhatikan beberapa perkembangan dalam bidang studi Kritik Teks Perjanjian Baru. Dalam membahas bukti eskternal, penulis akan mempertimbangkan aspek pregenealogical coherence antar saksi pendukung, sementara dalam menguji bukti internal, penulis akan mempertimbangkan secara khusus re-evaluasi terhadap validitas kanon lectio brevior potior. Singkatnya, dalam tulisan ini, penulis akan menunjukkan bahwa-bertentangan dengan apa yang pernah menjadi keyakinan penulis-ada alasan yang baik untuk mempercayai autentisitas epitet vioũ $\theta \varepsilon \circ \tilde{\text {. }}$

\section{MENIMBANG ULANG BUKTI EKSTERNAL}

Bukti eksternal yang mendukung bacaan pendek (tanpa epitet) maupun bacaan panjang (dengan epitet) sebenarnya cukup

According to Saint Mark. BlackNTC, (Peabody, MA: Hendrickson, 1991), 34. Ia menulis, "It is possible that it was added to the text subsequently, by a copyist, in order to make plain the truth about Jesus in the opening line; on the other hand, the phrase could have dropped out accidentally, owing to the similarity in the endings of the Greek words. Whichever is the true explanation, the phrase is certainly in keeping with Mark's own beliefs, and forms an appropriate heading to his book." Tan nampaknya juga sedikit ragu untuk memutuskan, meski ia nampak cenderung mendukung autentisitas gelar ini. Lihat Tan Kim Huat, The Gospel According to Mark. Asia Bible Commentary, (Manila: ATA, 2011), 21-2. Berbeda dengan Tan, Alan Cole mengakui bahwa bukti naskah yang ada bersifat tidak konklusif. Meski demikian, ia nampaknya condong mendukung bacaan pendek. Lihat R. Alan Cole, Mark. TNTC, (Downers Grove: IVP, 1989), 104.

6 Lihat Stefanus Kristianto, Evaluasi terhadap Pandangan Bart Ehrman mengenai Transmisi Teks Perjanjian Baru dan Implikasinya bagi Iman Kristen (Tesis MTh yang tidak diterbitkan; Lawang: STT Aletheia, 2015), 76-7; idem, "Did the Orthodox Corruption Occur Everywhere? Evaluating Bart Ehrman's Notion", dalam Jurnal Theologi Reformed Indonesia 8. 2, (Juli 2018). Perubahan pandangan penulis sama sekali tidak melemahkan tesis penulis dalam kedua karya tersebut, sebaliknya perubahan ini justru mempertegas tesis penulis bahwa orthodox corruption dalam transmisi teks Perjanjian Baru muncul dalam skala yang terbatas. 


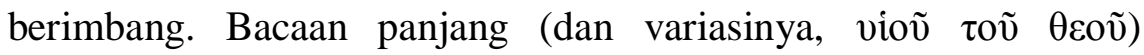
memang didukung oleh lebih banyak naskah Yunani, di antaranya $01^{1}$ ( , korektor pertama), 02 (A), 03 (B), 05 (D), 019 (L), $024(\mathrm{P})$, $032(\mathrm{~W}), 037(\Delta), f^{1}(1,118,131,209,1582, \mathrm{dsb}), f^{13}(13,69,124$, $174,230,346,543,788,826,828,983,1689,1709$, dsb), 33, 180, 205, 565, 579, 597, 700, 892, 1006, 1010, 1071, 1243, 1292, 1342, 1424,1505 , dan 2427, sedangkan bacaan pendek hanya didukung oleh $01^{*}(\kappa$, penyalin asli), $038(\Theta), 28,530,582,820,1021,1436$, $1555,1692,2430,2533$. Meski demikian, tiap-tiap bacaan ternyata memiliki saksi uncial yang baik. Bacaan panjang bisa ditemukan dalam Kodeks 03 (Vaticanus), sementara autentisitas bacaan pendek didukung oleh Kodeks $01^{*}$ (Sinaiticus). Karena alasan ini, tidak heran para sarjana sedikit mengalami kesulitan dalam memutuskan autentisitas epitet vioṽ $\theta \varepsilon$ ṽ berdasarkan bukti eskternal. Pertimbangan mereka akan lebih banyak didasarkan pada bukti internal. Sama dengan itu, meskipun editor UBS memilih memasukkan epitet vioṽ $\theta \varepsilon o \tilde{~ k e ~ d a l a m ~ t e k s ~ k r i t i k a l ~ m e r e k a, ~ t e t a p i ~}$ tim editor ini memutuskan memberi rating $\mathrm{C}$ (disertakan dengan keraguan cukup besar) untuk autentisitas epitet ini. Adapun yang melandasi pertimbangan tersebut: “ ... because of the antiquity of the shorter reading and the possibility of scribal expansion, it was decided to enclose the words within square brackets."7

Di tengah kesulitan ini, analisa pregenalogical coherence dari metode Coherence-Based Genealogical Method (CBGM) memberi pencerahan terhadap analisa bukti eskternal. Analisa pregenalogical coherence adalah sebuah analisa yang berupaya menemukan kesamaan teks antar saksi yang diwujudkan dalam bentuk persentase. Untuk menemukan koherensi antar saksi Injil Sinoptik, kritikus teks bisa menggunakan perangkat daring Parallel

${ }^{7}$ Bruce M. Metzger, A Textual Commentary on the Greek New Testament, $\left(4^{\text {th }}\right.$ Rev. Ed; London/New York: UBS, 1994), 62. 
Pericopes: Manuscripts Clusters $^{8}$ atau Parallel Pericopes: Find Relatives. ${ }^{9}$ Sedangkan bila kritikus teks Perjanjian Baru hendak menguji koherensi teks saksi-saksi Surat-Surat Umum, mereka bisa menggunakan perangkat daring Potential Ancestors and Desecendants. ${ }^{10}$ Asumsi mendasar dari tahap ini ialah bahwa semakin besar persentase koherensi teks, berarti semakin baik teks tersebut ditransmisikan oleh para saksi. ${ }^{11}$ Dengan menggunakan perangkat daring Parallel Pericopes: Manuscript Clusters $^{12}$ (dengan pengaturan standar) dihasilkan data untuk bacaan panjang sebagai berikut: ${ }^{13}$

\footnotetext{
${ }^{8}$ Bisa diakses di http://intf.uni-muenster.de/TT_PP/PP_Clusters.html

${ }^{9}$ Bisa diakses di http://intf.uni-muenster.de/PreCo/Coh1_PP.html.

${ }^{10}$ Bisa diakses di http://intf.uni-muenster.de/cbgm2/PotAnc5.html

${ }^{11}$ Untuk pengantar yang baik tentang analisa pregenealogical coherence, lihat Tommy Wasserman and Peter Gurry, A New Approach to Textual Criticism: An Introduction to the Coherence-Based Genealogical Method (Atlanta/Stuttgart: SBL/Deutsche Bibelgesellschaft, 2017), 37-58.
}

${ }^{12}$ Ada dua hal yang perlu diingat di sini. Pertama, untuk menggunakan perangkat daring Parallel Pericopes: Manuscript Clusters, nama saksi yang digunakan ialah penomoran ala Gregory-Aland dan bukan simbol huruf. Kedua, peringkat yang ditulis di sini disamakan dengan daftar yang dihasilkan perangkat, yang sebenarnya mengikut sertakan juga perbandingan naskah dengan initial text hasil rekonstruksi editor (A). Akibatnya, peringkat koherensi beberapa saksi sebenarnya bisa jadi jauh lebih tinggi. Sebagai contoh, kerabat terdekat nomor 2 dari 01 ialah 03. Akan tetapi, karena perangkat menyatakan bahwa kerabat terdekat 01 adalah $\mathrm{A}$, maka bisa dikatakan bahwa sebenarnya kerabat terdekat 01 ialah 03.

13 Analisis pregenealogical coherence terhadap teks Markus 1:1 juga pernah dilakukan oleh Wasserman dan Gurry. Meski detil analisis penulis sedikit berbeda dengan mereka, kesimpulan yang dihasilkan tetap sama. Lihat Wasserman and Gurry, A New Approach, 43-50. 
Jurnal Theologia Aletheia Volume 20 No.15 September 201889

\begin{tabular}{|c|c|c|c|c|}
\hline Saksi & $\begin{array}{c}\text { Kerabat } \\
\text { Terdekat } \\
\text { Dengan Bacaan } \\
\text { Panjang }\end{array}$ & $\begin{array}{l}\text { Persentase } \\
\text { (Ranking) }\end{array}$ & $\begin{array}{c}\text { Kerabat } \\
\text { Terdekat } \\
\text { Dengan Bacaan } \\
\text { Pendek }\end{array}$ & $\begin{array}{l}\text { Persentase } \\
\text { (Ranking) }\end{array}$ \\
\hline $01^{1}$ & 03 & $84.9(2)$ & $038(565-85.1)$ & $78.0(40)$ \\
\hline 02 & - & - & - & - \\
\hline 03 & 892 & $85.5(2)$ & $01^{*}$ & $84.9(3)$ \\
\hline 05 & 565 & $70.3(11)$ & $038(044-84.0)$ & $71.6(3)$ \\
\hline 019 & 892 & $88.0(2)$ & $01 *$ & $84.8(4)$ \\
\hline 024 & - & - & - & - \\
\hline 032 & - & - & - & - \\
\hline 037 & - & - & - & - \\
\hline 1 & 1582 & $99.4(1)$ & - & - \\
\hline 13 & 826 & $97.9(1)$ & - & - \\
\hline 33 & $892(03-85.5)$ & $85.4(1)$ & - & - \\
\hline 69 & 826 & $94.8(1)$ & - & - \\
\hline 118 & 209 & $95.4(1)$ & - & - \\
\hline 124 & 826 & $92.3(1)$ & - & - \\
\hline 131 & $*$ & $*$ & $*$ & $*$ \\
\hline 174 & $*$ & $*$ & $*$ & $*$ \\
\hline 205 & 209 & $98.5(1)$ & - & - \\
\hline 209 & 205 & $98.5(1)$ & - & - \\
\hline 346 & 826 & $95.8(1)$ & - & - \\
\hline 543 & 826 & $98.7(1)$ & - & - \\
\hline 565 & $*$ & $*$ & $*$ & $*$ \\
\hline 579 & $33(033-84.8)$ & $82.1(2)$ & - & - \\
\hline 700 & $*$ & * & * & $*$ \\
\hline 788 & 826 & $96.6(1)$ & - & - \\
\hline 826 & 543 & 98.7 (1) & - & - \\
\hline 828 & 826 & 96.7 (1) & - & - \\
\hline 892 & 019 & $88.0(2)$ & - & - \\
\hline 983 & 826 & 94.7 (1) & - & - \\
\hline 1071 & - & - & - & - \\
\hline 1342 & $*$ & $*$ & $*$ & $*$ \\
\hline 1424 & - & - & - & - \\
\hline
\end{tabular}




\begin{tabular}{|l|l|l|l|l|}
\hline 1582 & 1 & $99.4(1)$ & - & - \\
\hline
\end{tabular}

Sementara, dengan menggunakan perangkat daring Parallel Pericopes: Manuscript Clusters (dengan pengaturan standar) dihasilkan data untuk bacaan pendek sebagai berikut:

\begin{tabular}{|c|c|c|c|c|}
\hline Saksi & $\begin{array}{c}\text { Kerabat } \\
\text { Terdekat } \\
\text { Dengan } \\
\text { Bacaan } \\
\text { Panjang }\end{array}$ & $\begin{array}{c}\text { Persentase } \\
\text { (Ranking) }\end{array}$ & $\begin{array}{c}\text { Kerabat } \\
\text { Terdekat } \\
\text { Dengan } \\
\text { Bacaan } \\
\text { Pendek }\end{array}$ & $\begin{array}{c}\text { Persentase } \\
\text { (Ranking) }\end{array}$ \\
\hline $01^{*}$ & $\begin{array}{c}038(565- \\
85.1)\end{array}$ & $78.0(40)$ & 03 & $84.9(2)$ \\
\hline 038 & - & - & 565 & $85.1(1)$ \\
\hline 28 & $*$ & $*$ & $*$ & $*$ \\
\hline 1555 & $*$ & $*$ & $*$ & $*$ \\
\hline 1692 & $*$ & $*$ & $*$ & $*$ \\
\hline
\end{tabular}

Sebelum menafsirkan data di atas, ada beberapa hal yang perlu penulis jelaskan. Pertama, penulis hanya menampilkan saksi yang datanya dimiliki oleh perangkat daring. Beberapa saksi yang datanya tidak dimiliki oleh perangkat, tidak penulis ikut sertakan dalam tabel (misalnya 1006, 1010, 1243, 1292, 1505, 2427 untuk bacaan panjang, serta 530, 582, 820, 1021, 1436, 2430, 2533 untuk bacaan pendek). Kedua, penulis memberikan tanda garis atau dash (-) untuk menandakan bahwa dalam daftar yang dihasilkan oleh perangkat daring, tidak ditemukan adanya kerabat dekat yang mengandung bacaan yang dimaksud. Ketiga, tanda bintang atau asteriks (*) menunjukkan bahwa saksi yang bersangkutan tidak memiliki kerabat dekat yang persentase koherensinya lebih besar daripada perbandingan saksi tersebut dengan Majority Text (MT). Sebagai catatan, perangkat daring Parallel Pericopes: Manuscript Clusters hanya menampilkan kerabat dekat yang persentase koherensinya lebih tinggi daripada persentase perbandingan saksi 
tersebut dengan MT. Dengan kata lain, tanda asteriks dalam daftar di atas sebenarnya menunjukkan bahwa kerabat terdekat saksi tersebut ialah MT.

Dari dua tabel di atas, terlihat bahwa koherensi saksi-saksi pendukung bacaan panjang ternyata jauh lebih baik ketimbang koherensi saksi-saksi pendukung bacaan pendek. Hampir semua saksi pendukung bacaan panjang memiliki koherensi satu sama lain dalam persentase yang tinggi. Beberapa saksi pendukung bacaan panjang memang memiliki kerabat dekat yang mengandung bacaan pendek (misal $01^{1}, 03,05$, dan 019), tetapi persentase koherensinya masih lebih rendah bila dibandingkan koherensi saksi tersebut dengan saksi terdekat yang mengandung bacaan pendek. Saksi 019, misalnya, memang memiliki kerabat dekat yang mengandung bacaan panjang, yakni $01^{*}$ (84.8 persen). Hanya saja, persentase koherensinya ini masih lebih rendah dibanding koherensi 019 dengan 892 yang mencapai 88.0 persen. Hal yang sama juga berlaku dengan 03 , dan $01^{1}$. Satu-satunya perkecualian ialah 05 , sebab persentase koherensinya dengan saksi terdekat yang memiliki bacaan panjang lebih rendah dibandingkan koherensinya dengan saksi terdekat yang mengandung bacaan pendek. ${ }^{14}$

Bagaimanapun, hasil tersebut masih jauh lebih baik dibandingkan koherensi saksi-saksi pendukung bacaan pendek. Meski bacaan pendek didukung oleh $01^{*}$, tetapi kerabat terdekat saksi ini justru memiliki bacaan panjang (03, 84.9 persen). Kerabat terdekat saksi $01^{*}$ yang juga memiliki bacaan pendek ialah 038, tetapi koherensinya dengan $01 *$ termasuk sangat rendah, hanya sekitar 78 persen (peringkat 40). Lebih menarik lagi, ternyata

\footnotetext{
${ }^{14}$ Dalam analisisnya, Wasserman dan Gurry menuliskan bahwa saksi terdekat 05 yang memiliki bacaan panjang ialah 2737 dengan persentase 71.1 persen (peringkat 4), sedangkan saksi terdekat dengan bacaan pendek ialah 038 dengan persentase 71.6 persen (peringkat 3). Band. Wasserman dan Gurry, A New Approach, 47.
} 
kerabat terdekat 038 ialah 565, yang notabene memiliki bacaan panjang. Selain itu, 038 juga tidak memiliki kerabat dekat (dengan persentase di atas 80 persen) yang memiliki bacaan pendek. Hasil yang sama juga bisa ditemukan dalam tiga saksi lain, yakni 28, 1555, dan 1692. Ketiga saksi ini memiliki kerabat dekat MT. Mengingat MT juga mengandung bacaan panjang, ini berarti kerabat terdekat ketiga saksi ini juga memiliki bacaan panjang.

Seperti yang dijelaskan sebelumnya, asumsi mendasar dalam analisa pregenalogical coherence ialah bahwa semakin besar koherensi antar saksi pendukung sebuah bacaan, berarti semakin baik teks tersebut ditransmisikan. Dengan kata lain, saksi tersebut lebih mungkin mencerminkan teks asli. Bila demikian, ini berarti bacaan panjang lebih mungkin menjadi bacaan yang ditransmisikan dengan baik, sebab koherensi antar saksinya sangat baik. Sementara bacaan pendek nampaknya bukanlah bacaan yang mencerminkan teks asli, sebab selain koherensi antar saksinya cenderung rendah, kerabat terdekat saksi-saksi tersebut justru memiliki bacaan panjang. Pendeknya, analisa pregenealogical coherence menjadi sebuah bukti eksternal yang penting, yang mendukung autentisitas bacaan panjang.

\section{MENIMBANG ULANG BUKTI INTERNAL}

Berbicara seputar bukti internal, beberapa sarjana beranggapan bahwa bukti ini cenderung mendukung autentisitas bacaan pendek. Bart Ehrman adalah salah satu suara utama dalam kubu ini. Dalam tulisannya, setelah membantah beberapa argumen yang mendukung autentisitas bacaan panjang, ia menyimpulkan bahwa bacaan pendek lebih mungkin asli. Menurutnya, bacaan panjang ditambahkan secara sengaja oleh penyalin yang terkemudian dengan tujuan mengantisipasi dan melawan Kristologi 
Adopsionistik yang muncul di masa itu. ${ }^{15}$ Ehrman sebenarnya tidak memberikan argumen yang jelas bagaimana bukti internal mendukung autentisitas bacaan pendek. Ia hanya menunjukkan bahwa argumen pendukung bacaan panjang menurutnya tidak memiliki kekuatan. Selain itu, idenya mengenai perubahan karena polemik teologis juga lemah, mengingat epitet "Anak Allah" juga muncul dalam bagian lain Injil Markus (1:11; 3:11; 5:7; 9:7; 14:61; 15:39). Dengan kata lain, ada atau tidaknya epitet ini dalam Markus 1:1 sebenarnya tidak memengaruhi sedikit pun gambaran besar Markus tentang Yesus sebagai Anak Allah.

Berbeda dengan Ehrman, penulis kini melihat bahwa bukti internal cenderung mendukung autentisitas bacaan panjang. Mengingat penyalin Kristen nampaknya tidak mungkin menghilangkan epitet ini dengan sengaja, hilangnya epitet ini dalam beberapa kasus nampaknya disebabkan oleh faktor kesalahan yang tidak disengaja (unintentional error). Dalam konteks ini, salah satu penjelasan yang tidak boleh diabaikan begitu saja ialah kemungkinan terjadinya homoioteleuton (kesilapan menyalin karena akhiran yang sama dari sebuah rangkaian kata). Kemungkinan ini besar sebab lima kata terakhir dari Markus 1:1 memiliki akhiran yang sama -v (EYАГГЕ $\Lambda$ IOY $\bar{\Upsilon} \overline{\mathrm{X}} \bar{Y} Y \mathrm{IOY} \overline{\Theta Y} \rightarrow$

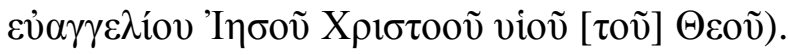

Dalam beberapa kasus, peluang terjadinya homoioteleuton ini semakin meningkat karena beberapa saksi pendukung bacaan pendek nampaknya memiliki ancestor atau vorlage yang menuliskan viós sebagai nomina sacra (entah dalam bentuk $\overline{\Upsilon \Upsilon}$ atau $\overline{\Upsilon I Y}$ ). Kemiripan huruf-huruf akhir yang menyusun kalimat awal Injil Markus ini tentu saja berpotensi menyebabkan homoioteleuton dalam proses transmisi Markus 1:1

15 Ehrman, The Orthodox Corruption, 72-5; idem, "The Text of Mark in the Hands of the Orthodox", 149-54. 
(ЕYАГГЕАIOYĪ $\overline{X \Upsilon \Upsilon Y \Theta Y)}$ ). Memang harus diakui bahwa tidak semua salinan teks Yunani menganggap viós sebagai nomina sacra. Penulisan nomina sacra secara konsisten hanya dikenakan

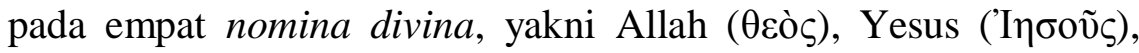

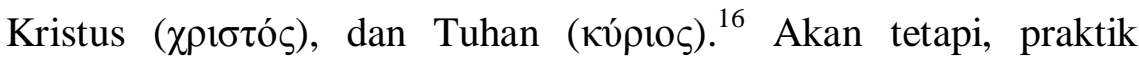
menuliskan viós sebagai nomina sacra ternyata bisa ditelusuri sampai kepada saksi-saksi terawal teks Perjanjian Baru, yakni beberapa papirus dari abada kedua dan ketiga. ${ }^{17}$ Karena itu, tentu tetap terbuka peluang yang besar bahwa para saksi pendukung bacaan pendek memiliki vorlage yang menuliskan vió $\varsigma$ sebagai nomina sacra dan yang kemudian menyebabkan problem dalam proses transmisi teks Markus 1:1.

Analisis ini bukanlah tanpa dasar. Fenomena ini kemungkinan besar memang terjadi dalam konteks kesalahan dan revisi Kodeks 01. Beberapa sarjana berpendapat bahwa sangat mungkin bila revisi pertama dalam Kodeks 01 (yang menambahkan epitet vioṽ $\theta \varepsilon$ ṽ) dilakukan oleh penyalin asli dan terjadi sebelum Kodeks tersebut meninggalkan scriptorium. ${ }^{18}$ Apa yang menarik, penyalin tersebut ternyata menambahkan kata vió $\varsigma$ dalam bentuk nomina sacra $(\overline{\mathrm{Y}})$. Bila diasumsikan bahwa penyalin Kodeks 01 menyalin teks vorlage apa adanya, ini berarti vorlage yang ia miliki

${ }^{16}$ Lihat Larry W. Hurtado, The Earliest Christian Artifacts: Manuscripts and Christian Origins, (Grand Rapids: Eerdmans, 2006), 95-134. Band. juga David Trobisch, The First Edition of the New Testament, (Oxford: OUP, 2000), 11-9. Dalam konteks para saksi teks Markus 1:1, Korektor $01^{1}$ dan Kodeks 02 memang menganggap vióc sebagai nomina sacra $(\overline{\mathrm{YY}})$, tetapi Kodeks B dan Kodeks D tidak menuliskannya sebagai nomina sacra.

${ }^{17}$ Hurtado, The Earliest Christian, 95-134.

18 Misalnya France, The Gospel of Mark, 48; Wasserman, "The 'Son of God' was in the Beginning (Mark 1:1)", 46. Di sini Wasserman merujuk pada edisi ketiga salah satu karya monumental Bruce Metzger, The Text of the New Testament. Akan tetapi, menariknya ide Metzger ini tidak bisa ditemukan pada edisi keempat. Alasannya, karena edisi tersebut telah mendapat sentuhan tambahan dari Ehrman. Seperti yang dijelaskan di awal, Ehrman merupakan pendukung autentisitas bacaan pendek. 
nampaknya juga menuliskan viós sebagai nomina sacra. Bila demikian, tentunya cukup beralasan bila disimpulkan bahwa karena alasan homoioteleuton, penyalin Kodeks 01 sebenarnya telah silap

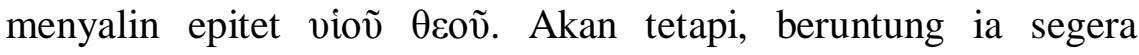
menyadari kesalahannya dan kemudian menambahkan epitet tersebut.

Beberapa sarjana memang menolak penjelasan ini. Mereka beranggapan bahwa Markus 1:1 terletak di awal kitab, sehingga lebih mungkin disalin saat penyalin ada dalam keadaan jauh lebih prima; dan karena disalin dalam keadaan yang jauh lebih prima, maka kecil kemungkinan mereka melakukan kesilapan. ${ }^{19}$ Dalam hemat penulis, argumen ini nampak penuh dengan asumsi. Misalnya, pandangan ini mengasumsikan bahwa penyalin pasti akan berhenti menyalin dan beristirahat segera setelah mereka menyelesaikan tugas menyalin kitab sebelumnya. Problemnya, para sarjana belum memiliki pengetahuan yang memadai mengenai mekanisme atau tata cara penyalinan para penyalin. Dengan demikian, anggapan 'kondisi prima' sebenarnya cenderung spekulatif. Selain itu, kalaupun mereka memang ada dalam kondisi yang prima, nyatanya kesalahan bisa dilakukan seseorang kapan saja: entah dalam kondisi prima ataupun lelah; baik di awal, di tengah, atau di akhir tulisan. Wasserman memberi contoh bahwa kelalaian menyalin nomina sacra memang bisa terjadi bahkan di awal penyalinan. Ia merujuk pada penyalin Kodeks F (010) yang

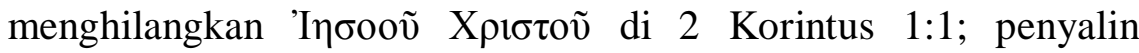
Kodeks 489 yang menghilangkan $\tau$ õ̃ $\Theta \varepsilon o \tilde{v}$ di ayat yang sama; penyalin pertama Kodeks Claromontanus (06) yang melewatkan

19 Ehrman, The Orthodox Corruption of Scripture, 73-4; idem, "The Text of Mark in the Hands of the Orthodox," 151-2; Head, "A Text-Critical Study of Mark 1:1," 629; Yarbro-Collins, Mark, 130. 
'I

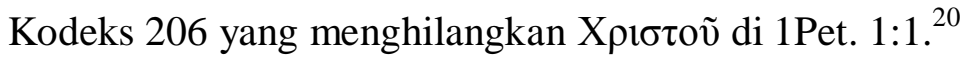

Dukungan bukti internal terhadap autentisitas bacaan panjang makin diperkuat oleh 'kanon baru' dalam studi kritik teks, yakni bahwa "bacaan yang lebih panjang lebih disukai" (lectio longior potior). Belakangan para kritikus teks menyadari bahwa kanon lama lectio brevior potior ("bacaan yang lebih pendek lebih disukai) merupakan kanon yang agak problematis bagi studi teks Perjanjian Baru. Epp mencatat bahwa kritik ini dimulai oleh E. C. Colwell di sekitar tahun enam puluhan. Studi Colwell menunjukkan bahwa para penyalin awal ternyata lebih cenderung menghilangkan dan memperpendek bacaan dan bukannya memperpanjang. ${ }^{21}$ Tesis Colwell ini makin dipertegas oleh studi mendetil James Royse. Senada dengan Colwell, Royse menyatakan bahwa studinya terhadap beberapa papirus awal menunjukkan bahwa kecenderungan para penyalin ialah menghilangkan atau menyingkat sebuah bacaan, sehingga konsekuensinya, bacaan yang lebih panjang seharusnya kini lebih disukai. ${ }^{22}$ Karena alasan ini, tidak heran Holmes lantas menuliskan, "In the light of Royse's

${ }^{20}$ Lihat Wasserman, "The 'Son of God' was in the Beginning (Mark 1:1)," 47.

${ }^{21}$ Lihat Eldon J. Epp, "Issues in New Testament Textual Criticism: Moving from the Nineteenth Century to the Twenty-First Century," dalam David Alan Black, ed., Rethinking New Testament Textual Criticism, (Grand Rapids: Baker, 2002), 27.

${ }^{22}$ Lihat magnum opus Royse, Scribal Habits in Early Greek New Testament Payri. NTTSD 36, (Leiden: Brill, 2008); untuk versi yang lebih pendek lihat idem, "Scribal Tendencies in the Transmission of theText of the New Testament," dalam Bart D. Ehrman and Michael W. Holmes, (ed.), The Text of the New Testament in Contemporrary Research: Essays on the Status Quaestionis. SD 46, (Grand Rapids: Eerdmans, 1995), 239-53. Studi singkat Peter Head juga menegaskan tesis ini. Lihat Peter Head, "Observations on Early Papyri of the Synoptic Gospels, Especially on the 'Scribal Habits'," Biblica 71 (1990): 240-7. 
study the venerable canon of lectio brevior potior is now seen as relatively useless at least for the early papyri.",23

Memang benar bahwa studi Colwell, Royse, dan Head terbatas hanya pada papirus-papirus awal. Akan tetapi, Elliot melihat bahwa kecenderungan ini nampaknya memang berlaku secara umum. Dia menegaskan, "in general, manuscripts tended to be accidentaly shortened rather than deliberately lengthened in the process of copying." 24 Di tempat lain, dia menjelaskan bahwa bacaan panjang lebih mungkin autentik sejauh bacaan tersebut konsisten dengan bahasa, gaya penulisan, dan teologi penulis kitab. ${ }^{25}$ Kriteria ini tentu sesuai dengan keberadaan epitet vioṽ $\theta \varepsilon o \tilde{v}$ dalam Injil Markus. Seperti yang disebutkan di atas, epitet ini muncul cukup sering dalam Injil Markus dan nampaknya merupakan epitet khas Injil ini $(1: 11 ; 3: 11 ; 5: 7 ; 9: 7 ; 14: 61 ; 15: 39)$. Karena itu, bila 'kanon baru' ini diterapkan secara konsisten, ini berarti bacaan yang lebih panjang jelas lebih mungkin menjadi bacaan yang autentik dibanding bacaan pendek. ${ }^{26}$

${ }^{23}$ Michael W. Holmes, "Reasoned Ecclecticism in New Testament Textual Criticism," dalam Ehrman and Holmes, The Text of the New Testament in Contemporrary Research, 343. Menurut penulis, kanon lectio brevior potior tidak perlu langsung dikesampingkan, melainkan harus digunakan dengan lebih hati-hati. Nyatanya, kanon ini masih berguna ketika kritikus teks berurusan dengan teks-teks dari kluster D (Western), misalnya.

${ }^{24}$ J. K. Elliot, "Can We Recover the Original Text of the New Testament? An Examination of the Role of Thoroughgoing Eclecticism," in idem, Essays and Studies in New Testament Textual Criticism (Cordova: El Amendro, 1992), 40. Dikutip dalam Epp, "Issues in New Testament", 28.

${ }_{25}$ J. K. Elliot, "Thoroughgoing Eclecticism in New Testament Textual Criticism", dalam Ehrman dan Holmes, The Text of the New Testament, 327.

${ }^{26}$ Dukungan lain untuk autentisitas bacaan panjang ialah bahwa epitet di 1:1 ini nampaknya membentuk sebuah inklusio dengan 15:39, dan dengan demikian menegaskan autentisitas bacaan ini. Lihat Brooks, Mark, 39; France, The Gospel of Mark, 48; Guelich, Mark 1-8:26, 6; Lane, The Gospel of Mark, 41; Wessel, "Mark," 8:621. 


\section{KESIMPULAN}

Seperti yang sudah disinggung di bagian awal, penulis pernah ada dalam kubu yang sama dengan para kritikus teks yang menolak autentisitas bacaan panjang. Akan tetapi, evaluasi ulang terhadap bukti eksternal dan internal (dengan memperhatikan perkembangan terakhir dalam studi teks Perjanjian Baru) menunjukkan bahwa bacaan panjang justru lebih mungkin autentik. Dengan menggunakan analisis pregenealogical coherence dari metode CBGM, bacaan panjang nampaknya lebih mungkin autentik sebab koherensi antara saksinya sangat baik. Ini berbeda dengan koherensi saksi-saksi pendukung bacaan pendek yang cenderung rendah. Bahkan, beberapa kerabat terdekat saksi tersebut justru memiliki bacaan panjang. Ketika berbicara mengenai bukti internal, dukungan terhadap autentisitas bacaan pendek diperkuat oleh kemungkinan terjadinya homoioteleuton dan juga 'kanon baru' dalam studi teks Perjanjian Baru, yakni bahwa 'teks yang lebih panjang lebih disukai” (lectio longior potior). Singkatnya, apa yang bisa disimpulkan dari pembahasan ini ialah bahwa bukti eksternal dan internal ternyata memberikan dukungan yang kuat terhadap autentisitas bacaan panjang. Dengan kata lain, epitet vioṽ $\theta \varepsilon$ õ̃ bukanlah epitet yang ditambahkan kemudian, melainkan gelar yang oleh Markus disematkan pada Yesus sejak awal mula tulisannya.

\section{DAFTAR RUJUKAN}

Aland, Kurt and Barbara Aland, The Text of the New Testament: An Introduction to the Critical Editions and to the Theory and Practice of Modern Textual Criticism. (trans. Errol F. Rhodes; $2^{\text {nd }}$ edition). Grand Rapids: Eerdmans, 1989. 
Black, David Alan, ed. Rethinking New Testament Textual Criticism. Grand Rapids: Baker, 2002.

Brooks, James A. Mark. NAC 23. Nashville, TN: Broadman \& Holman, 2001.

Cole, R. Alan. Mark. TNTC. Downers Grove: IVP, 1989.

Edwards, James R. The Gospel According to Mark. PNTC. Grand Rapids/Leicester: Eerdmans/Apollos, 2002.

Ehrman, Bart D. The Orthodox Corruption of Scripture: The Effect of Early Christological Controversies on the Text of the New Testament. Oxford: OUP, 1993.

Ehrman, Bart D. Studies in the Textual Criticism of the New Testament. Leiden: Brill, 2006.

Ehrman, Bart D. and Michael W. Holmes, (ed.) The Text of the New Testament in Contemporrary Research: Essays on the Status Quaestionis. SD 46. Grand Rapids: Eerdmans, 1995.

France, R. T. The Gospel of Mark. NIGTC. Grand Rapids/Carlisle: Eerdmans/Paternoster, 2002.

Gaebelein, Frank E. ed. Expositor's Bible Commentary Vol. 8. Grand Rapids: Zondervan, 1984.

Guelich, Robert A. Mark 1-8:26. WBC 34a. Dallas: Word, 2002. Head, Peter M. "A Text-Critical Study of Mark 1:1: 'The Beginning of the Gospel of Jesus Christ"', in New Testament Studies 37/4 (October 1991): 621-9.

Holmes, Michael W. (ed.). The Greek New Testament: SBL Edition. Atlanta/Bellingham, WA: SBL/Logos, 2010.

Hooker, Morna D. The Gospel According to Saint Mark. BlackNTC. Peabody, MA: Hendrickson, 1991.

Hurtado, Larry W. Mark. NIBC. Peabody, MA: Hendrickson, 1989.

Hurtado, Larry W. The Earliest Christian Artifacts: Manuscripts and Christian Origins. Grand Rapids: Eerdmans, 2006.

Kristianto, Stefanus. Evaluasi terhadap Pandangan Bart Ehrman mengenai Transmisi Teks Perjanjian Baru dan Implikasinya 
bagi Iman Kristen (Tesis M.Th. yang tidak diterbitkan; STT Aletheia, 2015).

Kristianto, Stefanus. "Did the Orthodox Corruption Occur Everywhere? Evaluating Bart Ehrman's Notion”, in Jurnal Theologi Reformed Indonesia (forthcoming 2018).

Lane, William L. The Gospel of Mark. NICNT. Grand Rapids: Eerdmans, 1974.

Marcus, Joel. Mark 1-8. AYBC. New Haven/London: YUP, 2008.

Metzger, Bruce M. A Textual Commentary on the Greek New Testament ( $4^{\text {th }}$ Rev. Ed). London/New York: UBS, 1994.

Royse, James R. Scribal Habits in Early Greek New Testament Payri. NTTSD 36. Leiden: Brill, 2008.

Stewart, Robert B. ed. The Reliability of the New Testament: Bart. D Ehrman and Daniel B. Wallace in Dialogue. Minneapolis: Fortress, 2011.

Tan Kim Huat, The Gospel According to Mark. Asia Bible Commentary. Manila: ATA, 2011.

Trobisch, David. The First Edition of the New Testament. Oxford: OUP, 2000.

Turner, David L. and Darrell L. Bock, Matthew and Mark. CBC 11. Carol Stream, Il: Tyndale House, 2005.

Wasserman, Tommy. "The 'Son of God' was in the Beginning (Mark 1:1)" in Journal of Theological Studies 62/1 (2011): 20-50.

Wasserman, Tommy and Peter Gurry, A New Approach to Textual

Criticism: An Introduction to the Coherence-Based Genealogical Method. Atlanta/Stuttgart: SBL/Deutsche Bibelgesellschaft, 2017.

Witherington III, Ben. The Gospel of Mark: A Socio-Rhetorical Commentary. Grand Rapids: Eerdmans, 2001.

Yarbro Collins, Adela. Mark. Hermeneia. Minneapolis: Fortress, 2007. 